\title{
EN SÍNTESIS
}

\section{Compromiso de Honor}

Con este título quiero comentar un aspecto puntual relacionado con nuestro quehacer de difusión de la actividad investigadora y que venimos haciendo en el CIT por más de 20 años. Esta difusión la hemos hecho principalmente a través de nuestras revistas internacionales y a través de congresos ya establecidos en el ambiente Ibero Americano. En todas estas actividades hay pagos involucrados ya que el CIT no cuenta con subsidios suficientes para solventar los altos costos de estas actividades. Los autores de artículos enviados a nuestras revistas y los participantes de nuestros congresos lo saben, como también saben el respeto que tenemos por nuestros compromisos académicos y económicos. Considerando algunas dificultades y ajuste a plazos para el pago de un servicio por parte de algún colega autor o autora hemos obviamente accedido en ocasiones a modalidades que garanticen la prestación adecuada del servicio para no perjudicar al autor o autora interesado. En un congreso que organizamos reciente ocurrió una situación como ésta con algunos colegas que no podían obtener los dineros para el pago oportuno de la cuota del congreso (congress fee). Por lo tanto, varios participantes firmaron con el CIT un "Compromiso de Honor", que deseo transcribir para que no quede duda de su contenido y alcances.

"Yo, Nombre y Apellido, firmo este Compromiso de Honor obligándome a pagar la inscripción establecida para el congreso CAIP'2009. Este pago se hará lo más pronto posible y no más tarde de la fecha del congreso. Mi firma en este compromiso garantiza que mi trabajo $N^{0}$ XX será incluido en las Actas del Congreso (Libro de Resúmenes en Papel y Actas completas en CD), siendo este el compromiso del Centro de Información Tecnológica (CIT), organizador del Congreso. Si no cumplo con lo establecido, yo estaré violando este Compromiso de Honor y mantendré una deuda con el CIT, deuda que el CIT buscará que se le pague por todos los medios razonables y legales.

Firmado en Mi Ciudad, Mayo 1, 2009.

Mi Nombre y Mi Firma"

Tenemos la más alta estima, consideración y confianza en nuestros pares Iberoamericanos y por ello nos atrevemos a proponer y aceptar este tipo de compromisos. Pero como en otros ámbitos de la vida no faltan personas de poca honorabilidad que desconocen compromisos contraídos argumentando asuntos no considerados en el documento firmado. Sobre el Compromiso de Honor, reproducido íntegramente arriba, recibimos de unos de estos personajes y después de realizado el congreso al que no asistió, una nota con peticiones adicionales no incluidas antes, como condición para realizar el pago al cual se comprometió. El argumento fue que su institución le exigía el envío por nuestra parte de los documentos del congreso, asunto que como se lee arriba no estaba en el compromiso. Debo recalcar que el CIT cumplió con su parte a cabalidad y el trabajo esta incluido en las Actas y lo más probable es que el autor lo muestre antes su institución y otras como trabajo correctamente presentado. Incluso debe tener las Actas completas que debe haber bajado de nuestra página Web.

He comentado este asunto con colegas honestos y hemos estado de acuerdo en lo siguiente: si esto me hubiese ocurrido a mí, habría pagado de mi bolsillo para obtener los documentos o habría realizado un depósito de garantía mientras mi institución efectuaba el pago por el que yo, no mi institución, me comprometí bajo Palabra de Honor. Para nosotros se trata solo de un poco de dinero y en verdad es que es lo menos importante. Pero, ¿qué pasa con quien faltó a su compromiso?. Si se trata de un académico universitario de una prestigiada universidad, como es este caso, ¿cómo le enseña a sus alumnos a cumplir sus compromisos?, ¿cómo los forma para que sean profesionales íntegros?, ¿cómo lo puede hacer si yo no es capaz de respetar sus compromisos?. En nuestro ultimo mail con el personaje deshonesto le deseamos suerte: "Gracias de todas maneras y éxito en sus actividades y en la vida".

Deseaba compartir esto con los lectores de Formación Universitaria y en particular con colegas recién en formación en estos asuntos académicos: que situaciones como las comentadas no manchen vuestra integridad, la que seguro tratarán de imitar nuestros educandos y nuestros hijos también.

\section{Formación Universitaria}

